\title{
Managers Effectively Applying Strengths Management and Emotional Intelligence
}

\author{
Dr. David E. Bartz \\ Professor Emeritus \\ Department of Educational Leadership \\ Eastern Illinois University \\ USA
}

\begin{abstract}
Strengths management and emotional intelligence are two concepts that have tremendous potential for managers to maximize their productivity and job satisfaction. Effectively blending these two concepts in practice will lead to actualizing managers' potential and, thus, their productivity and job satisfaction. This blending of strengths management and emotional intelligence will also create positive energy and motivation in those supervised and, in turn, enhances their performance and job satisfaction. Additionally, the work unit and organization will gain from the synergy generated from the marriage of strengths management and emotional intelligence by managers who effectively integrate these two concepts into their thinking and behaviors.
\end{abstract}

Keywords: strengths management, emotional intelligence, productivity and job satisfaction of managers

\subsection{Introduction}

Over the past decade strengths management and emotional intelligence are two concepts that have received considerable attention, having great potential in assisting managers to become more effective. If properly utilized, strengths management and emotional intelligence will result in managers being more productive and satisfied with their jobs. If managers properly apply strengths management and emotional intelligence to those they supervise, these individuals will also benefit through increased productivity and job satisfaction. Further, the overall productivity of the organization will be enhanced.

\subsection{Strengths Management ${ }^{1}$}

- Managers achieve maximum effectiveness by utilizing their strengths and managing their weaknesses, not through the elimination of weaknesses.

- Productivity of managers is maximized by focusing on strengths.

- Strengths management leads to an understanding of the difference between good and great.

- The study of strengths leads to productive conclusions; the study of weaknesses leads to ineffective conclusions.

- Managers are stronger when they have their successes and strengths clearly in mind.

- Managers should find out what they do not do well and stop doing it.

The above-listed axioms represent a "strengths-based mindset" for managers.

Many managers spend too much time and effort trying to improve weaknesses that, in reality, are never going to be much stronger. It is more productive for managers to use their energy in determining how to identify, maximize, and nourish their strengths. As Drucker (1966) noted, "The effective executive [manager] makes strengths productive. He knows one cannot build on weaknesses" (p. 71). The general well-being and feelings of gratification of managers are enhanced by meaningfully engaging their strengths in the work environment (Seligman, 2002).

It is important for managers to distinguish between their patterns of behavior and predispositions (preferences) and what constitutes their authentic strengths. Patterns of behaviors represent what a manager has previously done, which may not be her/his strengths. Strengths are those activities in which a person exhibits "consistent, near-perfect performance" (Buckingham, 2007, p. 21). Time is a limited resource, so it is imperative that managers understand that success comes from spending time on utilizing and enhancing strengths. 
Managers should have others do what they are responsible for getting done when they can do it as well or better. This assumes that the manager is in a position to delegate. It is essential, though, that the manager understands the importance of image. If by consistently assigning tasks to subordinates that can do them as well or better makes the manager look ineffective in the eyes of superordinates, there may be a problem.

Managers should avoid spending time in attempting to improve their weaknesses so there is ample time to nurture and further develop their strengths. It is useful for managers to seek feedback from others with whom they work about their strengths and weaknesses. This feedback can be compared to the manager's self-perceptions to more accurately identify strengths and weaknesses. Managers also need to develop habits in their work that prompt them to play to their strengths.

There are four myths that, if countered, can maximize performance for managers (Clifton \& Nelson, 1992): ${ }^{2}$

Myth 1: Fixing weaknesses will make everything all right. Many managers subscribe to the notion that fixingtheir weaknesses and those of staff members will make everyone stronger. This thinking has a commonsense appeal but is wrong and, at best, leads to average work by managers and staff members. The reality is that excellence is achieved by focusing on strengths and managing weaknesses, not through the elimination or "shoring up "of weaknesses.

Myth 2: Let the strengths take care of themselves. Managers should operate on the premise that their strengths and those of staff members need to be continually nourished and further developed, and that time is best spent on the intense focus and practice of strengths.

Myth 3: Success is the opposite of failure. Strengths and weaknesses have their own unique basis and are not the opposite of each other. Managers and staff members cannot enhance their understanding and development of strengths by studying and focusing on their weaknesses.

Myth 4: Everyone can do anything to which they put their mind. Each manager has a unique set of strengths and weaknesses. The truth is that a given manager can be strong on some factors and weak on others. Managers can be anything their strengths allow them to be but cannot be anything that requires outstanding performances in the area of their weaknesses. Managers will be most successful when they work in positions that play to their strengths because this will help them to be more engaged, productive, and satisfied (Buckingham \& Clifton, 2001).

Managers' strengths are often represented by functions from whichthey receive great satisfaction, and they are motivated to rapidly learn more about how to enhance competency for such functions. Another good indicator of the strength of a manager is his/her passion for a particular function.

Managers should not confuse strengths with advantages. For example, a manager's previously held position maybe an advantage when she/he applies for a new position in the present organization. This compares to a strength which could be represented by the manager being able to instantly identify, establish rapport, and quickly build a strong bond with those interviewing him/her for the new position.

It is important for managers to focus on a limited number of strengths and maximize them. This is in opposition to pursuing too many strengths and not being able to have the time, effort, or knowledge to meaningfully address each one. A manager should strive for mastery of the substance representing strength. For example, if a manager's strength is quickly building rapport with others in the work setting, she/he needs to be extremely knowledgeable of a wide array of techniques useful in creating rapport, as well as understanding how to apply these techniques.

While it seems that managers would know what constitutes their weaknesses, this is not always the case. The following are behavioral clues that help a manager to identify a weakness: (a) being overly defensive about performance and perceiving that criticisms by others are unjust, (b) developing an obsessive behavior in an unsuccessful attempt to correct a mistake, (c) experiencing "slow learning" by repeatedly returning to a particular behavior in an effort resulting in minimal improvement of a function, (d) repeating experiences that do not improve performance in an area, (e) having to think consciously through the steps of a given process or function analytically each time it is performed in an attempt to thoroughly understand it, (f) experiencing a lack of confidence from performing a function and wanting to get through the function to simply get it over, and (g) becoming burned out attempting to complete a task or function (Clifton \& Nelson, 1992).In summary, managers must be honest about "owning" their weaknesses.

Additional points for managers to consider in effectively utilizing strengths management are: 
- The best situation is when: (a) strengths match job responsibilities,(b) there is passion for the job responsibilities,(c) strengths are continually developed, and (d)weaknesses canbe avoided.

- There is no better way for managers to enjoy their jobs than to be doing what they are passionate about and performing at maximum efficiency.

- Others will sometimes overlook weaknesses if strengths are well-developed.

- Strengths can often overpower weaknesses, but occasionally acute weaknesses can overpower strengths.

\subsection{Emotional Intelligence}

Emotional intelligence is a combination of mental abilities and skills that help people to manage themselves successfully, and the demands of others, while effectively relating to others (Walton, 2012, p. 3; Bradberry \& Greaves, 2009). It includes using emotions to think creatively and make decisions (Bass \& Bass, 2008). Emotional intelligence also involves being consciously perceptive of self-emotions as well as the emotions of others in a given situation in order to understand the meaning of these emotions and using this information as input to effectively adjust actions (Robbins \& Judge, 2013).

Emotional intelligence stresses: (a) knowing oneself; (b) controlling emotions through self-management; (c) motivating oneself; (d) showing consideration, empathy, and feelings for others to build positive relationships; and (e) effectively using social skills to build an awareness that aids positive interactions and relationships for others (Bradberry \& Greaves, 2009; Goleman, 2015). Specific explanations for each of these five areas are: ${ }^{3}$

(1) Knowing yourself stresses being cognitively aware of your mood, and thoughts about a given mood at a given time, to help manage behavior. "Moods that start at the top tends to move the fastest because everyone watches the boss" (Goleman, Boyatzis, \& McKee, 2015, p. 31). A manager's moods influence staff members (Edinger, 2012).

When examining a negative mood (e.g., anger), it is usually best to reflect before reacting unless imminent danger exists. It is important to have "positive self-talks" to get the mind out of a negative mood. Thinking positive thoughts should prompt a positive mood. This also includes recognizing one's strengths and weaknesses, and viewing oneself in a positive but realistic light (Bradberry \& Greaves, 2009; Goleman, 1995).

(2) Controlling emotions through self-management is dependent upon the manager's acute awareness of the emotions for the purpose of remaining flexible and striving for positive behaviors. For some situations the manager's emotions can prompt an adrenaline rush that instantaneously results in behavior which may not be appropriate at that time. "Real results come from putting your momentary needs on hold to pursue larger, more important goals" (Bradberry \& Greaves, 2009, p. 33).

(3) Motivating self means using emotions to gain focus and energy to attain goals. This includes effectively dealing with delayed gratification (rewards) and stifling impulsiveness that can cause undesirable behaviors. It also means getting into a positive "flow" of activities that prompts outstanding performance (Seligman, 2011).

(4) Showing consideration, empathy, and feelings for others build on positive relationships. Relationship management is the manager's ability to use emotions to interact successfully with others in the work environment, both individually and with groups or teams. This stresses building positive relationships that bond the manager with others at work. To do so, the manager strives to understand the wants, needs, and emotions of others. Effective listening is a paramount skill in building effective relationships (Bradberry \& Greaves, 2009).

(5) Effectively using social skills to build awareness is accurately reading the emotions of other people in the work environment and understanding what is actually driving their behaviors. This requires the manager to attempt to "think and feel" as the other person does by putting him/herself in the situation of the other person (role reversal). Being an astute observer and listener is important, as well as reading nonverbal behaviors and observing each person to understand the context for her/his reactions in a given situation. "To be socially aware, you [the manager] have to spot and understand people's emotions while you're right in the middle of it - a contributing, yet astutely aware, member of the interaction" (Bradberry \& Greaves, 2009, p. 39).

Managers must recognize, understand, and acknowledge their negative thoughts and emotions and then develop the "emotional agility" to move past them. The process of emotional agility includes accepting the negative emotions, analyzing what situation prompted them, and then being agile enough to switch to positive actions to produce a solution to address the situation. This managing of negative emotions so that the result is a productive solution to a situation is called "workability" (David \& Congeton, 2015). 
Goleman (1995) observed that individuals have two minds: (1) the rational mind that is logical and (2) the emotional mind that is impulsive and sometimes illogical. Because of the potential for the emotional mind to be illogical, it is imperative for managers to pause and reflect before letting their emotional mind's thoughts be expressed either verbally or nonverbally.

If used effectively, emotions are powerful weapons for motivating the manager and others. Managers need to closely observe how their emotions are played out behaviorally and the impact - positive or negative-these behaviors have on the people with whom they interact. Next, the manager needs to solicit feedback from those with whom regular interactions take place to determine how they view the impact of the behaviors driven by the manager's emotions. Most importantly, the manager must have honest soul-searching reflections based on this feedback in comparing the images represented by the feedback to self-perceptions of the behaviors' impacts. Lastly, managers must comprehend the "ripple effect" of their emotions that are played out through behaviors that likely go beyond those with whom they have regular interactions and prompt others to form images of their emotional intelligence, positively or negatively.

\subsection{Summary}

The thesis of strengths management is that managers achieve maximum effectiveness by utilizing their strengths and managing their weaknesses, not through the elimination of weaknesses. The productivity of managers is maximized by focusing on strengths. Managers are stronger when they have their successes and strengths clearly in mind. Lastly, managers should determine what they do not do well and stop doing it.

Emotional intelligence involves managers being consciously perceptive of their emotions and those of others in a given situation, understanding their meaning, and using this information as input to effectively adjust actions. "Managers with high levels of emotional intelligence have an important edge over others who are not so adept" (Greenberg, 2013, p. 110). Emotional intelligence stresses: (a) knowing oneself; (b) controlling emotions through self-management; (c) motivating oneself; (d) showing consideration, empathy, and feelings for others in building positive relationships; and (e) effectively using social skills to build an awareness that aids positive interactions and relationships for others (Bradberry \& Greaves, 2009; Goleman, 2015). Managers' productivity and job satisfaction will be enhanced through the effective utilization of strengths management and emotional intelligence. Furthermore, applying these two concepts to the supervision of staff members will enhance their performance and increase job satisfaction.

\subsection{Footnote}

${ }^{1}$ The following are good resources for information pertaining to strengths management:Buckingham, M.\&Clifton, D.O. (2001). Now, discover your strengths. New York, NY:Gallup Press; Buckingham, M. (2007). Go put your strengths to work.New York, NY: Free Press; Clifton, D.O. \& Nelson, P. (1992). Soar with your strengths.New York, NY:Delacorte Press; Collins, J. (2011). Good to great: Why some companies make the leap... and others don't.New York, NY: HarperCollinsPublishers;Drucker, P.F. (1966). The effective executive. New York, NY:Harper and Row; Eureka Books. (2015). Key takeaways, analysis and review of Tom Rath'sStrengthFinder 2.0. Seattle, WA: CreateSpace Publishing; Rath, R. (2007). StrengthsFinder 2.0. NewYork, NY: Gallup Press; Rath, T. \& Conchie, B. (2008). Strengths based leadership: Great leaders, teams, and why people follow.New York, NY:Gallup Press; Zenger, J.H.\& Folkman, J. (2009). The extraordinary leader: Turning good managers into great leaders. New York, NY: McGraw-Hill.

${ }^{2}$ Based in part on Bartz, D. \& Bartz, D.T. (2017). Strengths management, realistic optimism, and impressions management for managers. International Journal of Organizational Theory and Development, 5(1), 1-10.

${ }^{3}$ Based in part on Bartz, D., Thompson, K., \& Rice, P. (2017). Managers helping themselves "be their best." International Journal of Management, Business, and Administration, 20(1), 1-8.

\subsection{References}

Bartz, D. \& Bartz, D.T. (2017). Strengths management, realistic optimism, andimpressions management for managers. International Journal of Organizational Theory and Development, 5(1), 1-10.

Bartz, D., Thompson, K., \& Rice, P. (2017). Managers helping themselves “betheir best." International Journal of Management, Business, andAdministration, 20(1), 1-8.

Bass, D.M. \&Bass, R. (2008). The Bass handbook of leadership, $4^{\text {th }}$ edition.New York, NY: FreePress. 
Bradberry, T. \& Greaves, J. (2009). Emotional intelligence 2.0. San Diego, CA:Talent Smart.

Buckingham, M.\& Clifton, D.O. (2001). Now, discover your strengths.New York, NY: Gallup Press.

Buckingham, M. (2007). Go put your strengths to work. New York, NY: FreePress.

Clifton, D.O. \& Nelson, P. (1992). Soar with your strengths. New York, NY:Delacorte Press.

Collins, J. (2011). Good to great: Why some companies make the leap... andothers don't. New York, NY: HarperCollins Publishers.

David, S. \&Congeton, C. (2015). Emotional agility. InOn emotional intelligence(pp. 119-126). Boston, MA:HarvardBusiness Review Press.

Drucker, P.F. (1966). The effective executive. New York, NY:Harper and Row.

Edinger, S. (2012). Three ways leaders make emotional connections. Retrievedfromhbr.org/2012/10/three-waysleaders-make-an-emo

Eureka Books. (2015). Key takeaways, analysis and review of Tom Rath'sStrengthFinder 2.0. Seattle, WA: CreateSpace Publishing.

Goleman, D. (1995). Emotional intelligence. New York, NY: Bantam Books.

Goleman, D. (2015). What makes a leader? InOn emotional intelligence(pp. 1-2). Boston, MA: Harvard Business Review.

Goleman, D., Boyatzis, R. \&McKee, A. (2015). Primal leadership: The hiddendrivers ofgreat performance. Boston, MA: Harvard Business Review.

Greenberg, J. (2013). Managing behavior in organizations, $6^{\text {th }}$ edition. Boston,MA:Pearson.

Rath, R. (2007). Strengths finder 2.0. New York, NY:Gallup Press.

Rath, T. \& Conchie, B. (2008). Strengths based leadership: Great leaders, teams, and whypeople follow. New York, NY: Gallup Press.

Robbins, S.P. \& Judge, T.A. (2013). Organizational behavior. Boston, MA:Pearson.

Seligman, M.E.P. (2011). Flourish. New York, NY: ATRIA.

Seligman, M.E.P. (2002). Authentic happiness: Using positive psychology torealize yourpotential for lasting fulfillment. New York, NY:Free Press.

Walton, D. (2012). Emotional intelligence: A practical guide. New York, NY:MJF Books.

Zenger, J. H.\& Folkman, J. (2009). The extraordinary leader: Turning goodmanagers into great leaders. New York, NY: McGraw-Hill. 